\title{
Toward Marker-assisted Breeding for Root Architecture Traits in Southern Highbush Blueberry
}

\author{
Gerardo H. Nunez, Hilda Patricia Rodríguez-Armenta, Rebecca L. Darnell, \\ and James W. Olmstead ${ }^{1}$ \\ Horticultural Sciences Department, University of Florida, P.O. Box 110690, Gainesville, FL 32611
}

\begin{abstract}
Additional INDEX words. Vaccinium corymbosum, Vaccinium arboreum, heritability, root depth, genotyping by sequence
Abstract. Root growth and root system architecture (RSA) are affected by edaphic and genetic factors and they can impact plant growth and farm profitability. Southern highbush blueberries [SHBs (Vaccinium corymbosum hybrids)] develop shallow, fibrous root systems, and exhibit a preference for acidic soils where water and ammonium are readily available. The amendments used to create these soil conditions negatively affect the profitability of SHB plantations. Hence, breeding for RSA traits has been suggested as an alternative to soil amendments. Vaccinium arboreum is a wild species that is used in SHB breeding. $V$. arboreum exhibits greater drought tolerance and broader soil pH adaptation than SHB, and-according to anecdotal evidence-it develops deep, taproot-like root systems. The present study constitutes the first in-depth study of the RSA of Vaccinium species with the intention of facilitating breeding for RSA traits. Root systems were studied in rhizotron-grown seedling families. In separate experiments, we tested the effect that growth substrate and family pedigree can have on root growth and RSA. Subsequently, a genotyping by sequence approach was used to develop single nucleotide polymorphism (SNP) markers that could be used along with the phenotyping method to investigate the heritability of RSA traits and look for marker-trait associations. We found that RSA is affected by growth substrate and family pedigree. In addition, we found that $V$. arboreum exhibited greater maximum root depth and a lower percentage of roots in the top $8 \mathrm{~cm}$ of soil than $\mathrm{SHB}$, and interspecific hybrids generally exhibited intermediate phenotypes. Also, we found that RSA traits exhibit moderate to low heritability and genetic correlations among them. Finally, we found 59 marker-trait associations. Among these markers, 37 were found to be located in exons, and 16 of them were annotated based on protein homology with entries in National Center for Biotechnology Information (NCBI) GenBank. Altogether, the present study provides tools that can be used to breed for root architecture traits in SHB.
\end{abstract}

Root growth and RSA are affected by edaphic and genetic factors. Soil characteristics such as mechanical impedance, moisture content, and nutrient availability can affect the size of the root system (Gioia et al., 2015; Hund et al., 2009; Jin et al., 2015), but their effects go beyond biomass accumulation. Edaphic and genetic factors also affect the root growth angle, average root diameter, and maximum root depth (Hund et al., 2009; Jin et al., 2015; Nagel et al., 2015) of various plant species. Similarly, the availability of nitrogen, phosphorus, and other elements can affect root branching, secondary root length, and maximum root depth (Gioia et al., 2015; Lambers et al., 2015; York et al., 2015). Although there is a growing body of literature documenting the edaphic factors that affect root growth and RSA of agronomic crops like wheat [Triticum sp. (Gioia et al., 2015; Jin et al., 2015; Nagel et al., 2015)] and maize [Zea mays (Hund et al., 2009; York et al., 2015)], research about the edaphic factors that affect root growth and RSA of horticultural crops, particularly the SHB, is lacking.

A cultivated specialty crop, SHB is derived from interspecific crosses between $V$. corymbosum and other Vaccinium species, including Vaccinium darrowii and Vaccinium virgatum (Brevis et al., 2008). SHB plants develop shallow, fibrous root systems (Bryla and Strik, 2007), and exhibit a preference

Received for publication 22 Apr. 2016. Accepted for publication 2 June 2016. This material is based on work that is supported by the National Institute of Food and Agriculture, U.S. Department of Agriculture, under award number 2009-02533.

${ }^{1}$ Corresponding author. E-mail: jwolmstead@ufl.edu. for growth on acidic soils ( $\mathrm{pH}<5.5)$ (Coville, 1910; Finn et al., 1993) where ammonium is the predominant form of nitrogen (Pritts and Hancock, 1992). These characteristics are relatively rare in agricultural soils. Consequently, SHB growers use costly soil amendments to provide favorable conditions for SHB cultivation (Williamson et al., 2015).

A related species with different soil adaptation and RSA is $V$. arboreum. This species can withstand growth in higher $\mathrm{pH}$ (up to $\mathrm{pH}$ 6.4) and mineral, drought-prone soils (Stockton, 1976). In addition, $V$. arboreum plants exhibit greater capacity for nitrate uptake than SHB plants (Poonnachit and Darnell, 2004), andaccording to field-level observations- $V$. arboreum plants develop deep, taproot-like root systems (Lyrene and Brooks, 1995). Although there is a lack of quantitative data about the roots of SHB and $V$. arboreum plants grown under the same conditions, deeper root systems in other species have been shown to confer an adaptive advantage in soils where water (Padilla and Pugnaire, 2007; Pinheiro et al., 2005) and nitrate (Gastal and Lemaire, 2002; King et al., 2003) percolate to deeper horizons. Moreover, deeper root systems encounter increasing soil acidity at greater soil depths (Lynch and Wojciechowski, 2015), which would be an adaptive advantage for acid-loving plants like Vaccinium species. Hence, the RSA of $V$. arboreum might be related to its soil adaptation. These RSA traits and the fact that $V$. arboreum has been previously used in SHB breeding (Lyrene and Olmstead, 2012; Olmstead et al., 2013) make $V$. arboreum a potential source of RSA traits that could be used to expand the soil adaptation of SHB. 
Breeding for RSA traits is underway in other crop species. Plant breeders have identified genetic sources of desirable root growth and RSA traits in domestic (Fita et al., 2008; Henry et al., 2012; Khan et al., 2012; Steele et al., 2006) and wild (Dias et al., 2004; Fita et al., 2006; Johnson et al., 2000) populations of many species. Since phenotypic selection for root traits remains largely unfeasible due to the challenge of large-scale phenotyping below ground (Kuijken et al., 2015), breeding for root growth and RSA traits has focused on the development of tools for marker-assisted selection (MAS). Accordingly, a multitude of quantitative trait loci (QTL) and molecular markers that are associated with root growth (Khan et al., 2012) and RSA traits such as root length (Ron et al., 2013; Steele et al., 2006), diameter (Li et al., 2015), growth angle (Hamada et al., 2012), branching (Fita et al., 2008), and depth (Johnson et al., 2000) have been identified. Although less frequent, MAS has been successfully used to create breeding lines with optimal RSA traits in maize and rice [Oryza sativa (Liu et al., 2012; Steele et al., 2006)]. However, to date, there has been limited application of root phenotyping and MAS in SHB.

The present study focuses on the edaphic and genetic factors affecting root growth and RSA in SHB, V. arboreum, and their interspecific hybrids. Considering that roots of Vaccinium species are understudied with respect to RSA, and that $V$. arboreum is a promising source of RSA traits for SHB breeding, we set out to identify a rooting substrate that allows practical phenotyping of Vaccinium species' roots. Then, we explored family-level differences between SHB and $V$. arboreum grown under similar conditions. Finally, we used an interspecific family with $V$. arboreum introgression to search for molecular markers associated with RSA traits. We hypothesized that: a) growth substrate affects the RSA of Vaccinium species, b) $V$. arboreum seedlings exhibit deeper root systems than SHB seedlings, and interspecific hybrids exhibit intermediate phenotypes, and c) deoxyribonucleic acid (DNA) markers could be associated with one or more RSA traits from $V$. arboreum.

\section{Materials and Methods}

Each of the previously mentioned hypotheses was tested in a separate experiment. We refer to seedlings from the same controlled cross or open pollination event as families, and pedigrees of the families used for each study are in Table 1. Although all SHB genotypes are interspecific hybrids, in the present study, a family was considered SHB if it did not have introgression from a pure Vaccinium species source for over three generations. The pollen sources for the open-pollinated $V$. arboreum families used were assumed to be from the $V$. arboreum due to the bloom timing (average bloom date of 1 Feb. through 1 Mar. for SHB, V. virgatum, and hybrids vs. 1 May onwards for $V$. arboreum) and ploidy level differences between $V$. arboreum, $\mathrm{SHB}$, and $V$. virgatum.

Seeds were germinated in $3.8-\mathrm{L}$ pots filled with sphagnum peatmoss (peat) in a temperature-controlled greenhouse under intermittent mist as previously described (Moore, 1965). When the average seedling reached $5 \mathrm{~cm}$ height from the soil line, seedlings were transplanted to bench-top rhizotrons. Bench-top rhizotrons were built with two $37.5 \times 37.5-\mathrm{cm}$ glass plates and three $37.5 \times 3.0 \times 3.5-\mathrm{cm}$ plastic inserts. Plastic inserts were used to close off the space between three of the four sides of the glass plates, forming a container that fit $\approx 3100 \mathrm{~cm}^{3}$ of substrate
(Fig. 1A). In Expts. 1 and 2, there were three seedlings per rhizotron. In Expt. 3, there were two seedlings per rhizotron. After transplant, rhizotrons were placed as cassettes in racks holding 12 rhizotrons (Fig. 1B). Each rack was then wrapped with black polyurethane plastic to further exclude light from the root compartments, such that only the substrate surface and growing seedlings were exposed. All experiments were run in greenhouses where daily temperature ranged between 10.3 and $37.8^{\circ} \mathrm{C}$, with daylength ranging between $11 \mathrm{~h} 46 \mathrm{~min}$ and $14 \mathrm{~h} 2 \mathrm{~min}$, and average photosynthetic photon flux of $521 \mu \mathrm{mol} \cdot \mathrm{m}^{-2} \cdot \mathrm{s}^{-1}$. Rhizotrons were watered as needed and fertilized weekly with $6 \mathrm{~g} \cdot \mathrm{L}^{-1}$ of $20 \mathrm{~N}-8.7 \mathrm{P}-16.6 \mathrm{~K}$ soluble fertilizer with micronutrients (Tracite; Helena Chemical Co., Collierville, $\mathrm{TN}$ ) for the duration of the experiments. All plants were harvested at the same time; when the deepest roots of the largest plant in each experiment reached the bottom of the rhizotron.

To access the root systems, one of the glass plates in each rhizotron was removed and a nail board (four 5.72-cm nails per $6.5 \mathrm{~cm}^{2}$ ) was put in its place to minimize root movement and breakage. Calipers were used to determine the in situ maximum root depth of each seedling before flushing the substrate away with tap water. In Expt. 1, clean roots were spread in transparent trays filled with tap water for scanning. In Expts. 2 and 3, roots were stained with $5 \mathrm{~g} \cdot \mathrm{L}^{-1}$ Neutral Red (Sigma-Aldrich, St. Louis, MO) for $24 \mathrm{~h}$ as per Bouma et al. (2000) before transfer to the trays for scanning. Longer staining periods and different dyes produced comparable results in a preliminary experiment (data not shown). Where necessary, root systems were split into more than one part before scanning to reduce root overlap in the images. This was accomplished by cutting at the highest order root available, and scanning this root with all its attached lower order roots in a separate image. Roots were scanned on a scanner (LX1100; Seiko Epson Corp., Tokyo, Japan) at a resolution of 600 dots per inch (dpi) in Expt. 1 and 800 dpi in Expts. 2 and 3. Scanning at resolutions up to $1000 \mathrm{dpi}$ did not yield significantly different results than scanning at 800 dpi in a preliminary experiment (data not shown). The resulting images were grayscale TIFF files ( 8786 pixels wide $\times 12,251$ pixels long) and they were analyzed using WinRhizo Pro 2013b (Regent Instruments, Quebec, QC, Canada). RSA variables measured were total root length, total root volume, total root surface area, specific root length [SRL (meters of root length per gram of root dry weight)], number of root branching events, number of root tips, and average root diameter. To ameliorate overestimation of root tips when root systems were split, the number of root tips was corrected by subtracting the number of split points from the number of root tips calculated by the software. Given that previous studies have found weak correlation between root diameter and root order (ValenzuelaEstrada et al., 2008), we used the count of root tips in a root system as a proxy to count first-order roots. Previously, root tips have been used as indirect measurement of root branching (Fita et al., 2008). After scanning, roots and shoots were dried at $72{ }^{\circ} \mathrm{C}$ to a constant weight, unless otherwise noted.

\section{Expt. 1: substrate effect}

To test the effect of growth substrate on root growth and RSA of Vaccinium species, bench-top rhizotrons were filled with one of two substrate treatments: peat or a 3:1 peat:perlite mixture. Nine uniform seedlings per family, from five different families (Table 1), were transplanted to rhizotrons filled with each substrate treatment and grown for $77 \mathrm{~d}$ before harvest. 
Table 1. Pedigree of Vaccinium families used in three separate experiments to study the effect that substrate and pedigree have on root system architecture and to develop molecular markers to breed for root system architecture traits.

\begin{tabular}{|c|c|c|}
\hline Expt. & Family name & Pedigree \\
\hline \multirow[t]{4}{*}{ 1: Substrate effect } & $\mathrm{S} 1$ & Open pollinated diploid Vaccinium arboreum \\
\hline & S2 & FL92-255 $\times$ Tifblue $^{z}$ \\
\hline & S3 & FL10-529 $\left(\right.$ Scintilla $^{y} \times$ FL06-730 $\left.{ }^{x}\right) \times$ FL08-496 $\left(\right.$ FL91-333MIK $^{y} \times$ FL06-754 $\left.^{y}\right)$ \\
\hline & S5 & 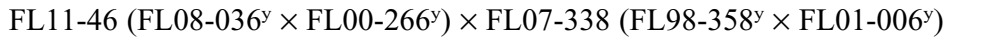 \\
\hline \multirow[t]{5}{*}{ 2: Pedigree effect } & P1 & FL11-1000 ${ }^{\mathrm{w}} \times$ FL $11-1001^{\mathrm{w}}$ \\
\hline & P2 & FL12-22 $($ FL09-006 $\times$ FL01-050 $) \times$ FL06-360 IV $\left(\right.$ FL03-027 $\times$ Windsor $\left.^{\mathrm{y}}\right)$ \\
\hline & P4 & 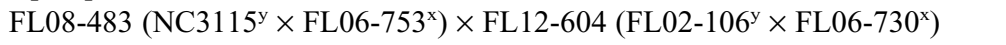 \\
\hline & P5 & FL10-678 (Bluecrisp ${ }^{\mathrm{y}} \times$ FL06-730 $\left.^{\mathrm{x}}\right) \times$ Flicker $^{\mathrm{y}}$ \\
\hline & P6 & FL10-616 (Farthing ${ }^{\mathrm{y}} \times$ FL08-447 F1) $\times$ Flicker $^{\mathrm{y}}$ \\
\hline 3: Marker-trait association & G1 & Southern Belle ${ }^{y} \times$ FL08-467 $\left(\right.$ Primadonna $^{y} \times$ FL06-753 $^{x}$ ) \\
\hline
\end{tabular}

\section{${ }^{\mathrm{z}}$ Vaccinium virgatum.}

${ }^{y}$ Southern highbush blueberry (SHB). Although all SHB genotypes are interspecific hybrids, in the present study, individuals or families were considered SHB if they did not have introgression from a pure Vaccinium species source for over three generations.

${ }^{\mathrm{x}}$ Colchicine-induced tetraploid $V$. arboreum.

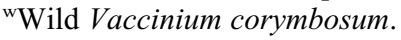

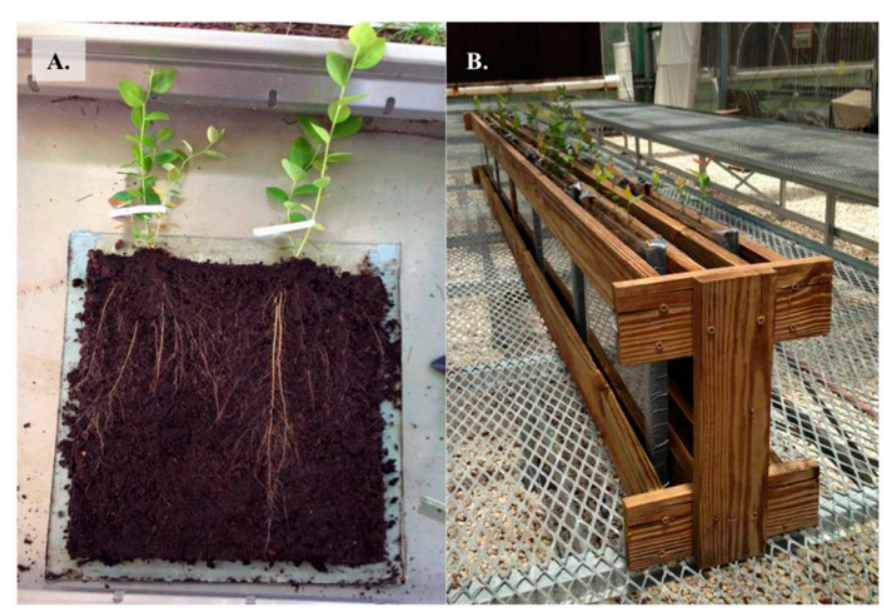

Fig. 1. Bench-top rhizotron system used to study the root system architecture of Vaccinium species. (A) Open bench-top rhizotron showing two Vaccinium species seedlings $69 \mathrm{~d}$ after transplant. (B) Rack used to hold bench-top rhizotrons during experiments. Racks were wrapped with black polyurethane plastic to exclude light from the root compartments, such that only the substrate surface and growing seedlings were exposed during experiments (not shown).

Data for RSA traits were compared between substrate treatments across families (main effect) or between substrate treatments within each family (interaction). Shoots from four randomly selected seedlings per family $\times$ substrate combination were destructively harvested as above.

\section{Expt. 2: pedigree effect}

To test the effect of $V$. arboreum introgression on root growth and RSA of Vaccinium species, 21 uniform seedlings from each of six additional families (Table 1) were transplanted to bench-top rhizotrons filled with peat. Roots and shoots from all seedlings were harvested as indicated above after $67 \mathrm{~d}$ of growth. In addition to the previously described data collection, a visual estimate of the percentage of roots in the top $8 \mathrm{~cm}$ of soil was recorded for each plant at the time of harvest. This depth corresponded to about $1 / 4$ of the depth of the rhizotron, and was chosen because previous research found that the majority of $V$. corymbosum roots was in the top $1 / 4$ of the soil profile (Bryla and Strik, 2007). Data were compared among families, making each seedling a pseudo-replication of the pedigree treatment.

Statistical AnALYsis. Expts. 1 and 2 followed a randomized complete block design where substrate treatment (Expt. 1) or family pedigree (Expt. 2) were independent variables and rhizotrons were the blocking variable. Dry weight data were analyzed with generalized linear models (proc GLM). RSA data were analyzed through a generalized linear mixed model (proc GLIMMIX), where substrate treatment, family, and/or their interaction were qualitative independent variables, and root dry weight was used as a covariate. Treatments were compared after normalizing for root dry weight. This was done since previous studies found that root system size (measured as fresh or dry weight) confounded size-independent variation in RSA traits (Fita et al., 2008; Johnson et al., 2000). Where significant interactions were found, interaction terms were sliced by family. Analyses were carried out in SAS (version 9.3; SAS Institute, Cary, NC).

\section{Expt. 3: marker-trait association}

To identify molecular markers that are associated with RSA traits, 267 seedlings from a pseudo-backcross family (Table 1) were transplanted to bench-top rhizotrons filled with peat. After $69 \mathrm{~d}$ of growth, seedlings were harvested as above. Since the pseudo-backcross family was of interest to the blueberry breeding program, individuals were not destructively harvested at the end of the experiment and RSA traits were not sizeadjusted. Previously, others have successfully used unadjusted RSA data to study the genetic control of RSA traits (Ron et al., 2013), and similar QTL have been found where size-adjusted and unadjusted data were used simultaneously (Johnson et al., 2000; Khan et al., 2012).

Leaf tissue from each seedling was used to extract total genomic DNA using the E-Z 96 ${ }^{\circledR}$ Plant DNA Kit ${ }^{\mathrm{T}}$ (Omega Bio-Tek, Norcross, GA). Then, DNA was quantified using Quanti-i $T^{\text {TM }}$ PicoGreen ${ }^{\circledR}$ dsDNA Assay $\mathrm{Kit}^{\mathrm{T} M}$ (Invitrogen, Grand Island, NY) and DNA libraries were built as previously described 
(Bhakta et al., 2015). Briefly, $400 \mathrm{ng}$ of DNA from each individual were digested for $2 \mathrm{~h}$ at $37^{\circ} \mathrm{C}$ with 1 unit of PstI-HF ${ }^{\circledR}$ restriction enzyme (New England BioLabs, Ipswich, MA), in a mix containing $1 \times$ buffer and $18 \mathrm{nM}$ adapter mix (final volume $20 \mu \mathrm{L}$ ). The adapter mix contained $30 \mathrm{nM}$ of barcode and $30 \mathrm{nM}$ of common adapter that were annealed separately in a thermocycler program consisting of $95{ }^{\circ} \mathrm{C}$ for $2 \mathrm{~min}$, ramp down to $25{ }^{\circ} \mathrm{C}$ (rate $0.1{ }^{\circ} \mathrm{C} \cdot \mathrm{s}^{-1}$ ), $25{ }^{\circ} \mathrm{C}$ for $30 \mathrm{~min}$, and hold at $4{ }^{\circ} \mathrm{C}$. Sequences of common adapters can be found in Supplemental Table 1. Following digestion, DNA was ligated to the adapters using $2.5 \mu \mathrm{L}$ of T4 DNA ligase (400 CEU/ $\mu \mathrm{L}$; New England BioLabs), $5 \mu \mathrm{L}$ of $10 \times$ T4 Ligase Buffer, and $22.5 \mu \mathrm{L}$ of sterile $\mathrm{H}_{2} \mathrm{O}$. The ligation reaction was incubated at $25^{\circ} \mathrm{C}$ for $1 \mathrm{~h}$, followed by a 30 -min incubation at $65^{\circ} \mathrm{C}$ to inactivate the ligase. Then, samples were cleaned by filtration through a Millipore ${ }^{\circledR}$ MultiScreen $^{T M}$ PCR filter plate (EMD Millipore, Billerica, MA) that had been soaked with $100 \mu \mathrm{L}$ of DNA grade $\mathrm{H}_{2} \mathrm{O}$ (Sigma-Aldrich). Samples were diluted with $150 \mu \mathrm{L}$ of DNA grade $\mathrm{H}_{2} \mathrm{O}$ before applying a tension of $25 \mathrm{~cm}$ of $\mathrm{Hg}$ for $15 \mathrm{~min}$ in a vacuum manifold. DNA was eluted from the filter using $30 \mu \mathrm{L}$ DNA grade $\mathrm{H}_{2} \mathrm{O}$ as per manufacturer's instructions. Following this, a polymerase chain reaction (PCR) reaction was set up with $8 \mu \mathrm{L}$ of cleaned DNA, $1 \times$ PCR buffer, $1.5 \mathrm{~mm} \mathrm{MgCl}_{2}, 200 \mu \mathrm{M}$ dNTPs, $0.5 \mu \mathrm{M}$ of each primer, and 0.025 units of GoTaq polymerase (final volume $50 \mathrm{~mL}$ ). Primers contained common forward and reverse sequences (Supplemental Table 2), as well as 4 to 8 bases-long barcodes on the forward primer that were used to multiplex the sequencing reaction (Supplemental Table 3 ). The PCR program consisted of $72{ }^{\circ} \mathrm{C}$ for $3 \mathrm{~min}, 98^{\circ} \mathrm{C}$ for $30 \mathrm{~s}, 22$ cycles of $98^{\circ} \mathrm{C}$ for $30 \mathrm{~s}, 65^{\circ} \mathrm{C}$ for $30 \mathrm{~s}$, and $72{ }^{\circ} \mathrm{C}$ for $30 \mathrm{~s}$, followed by a final elongation step at $72{ }^{\circ} \mathrm{C}$ for $5 \mathrm{~min}$ and hold at $4{ }^{\circ} \mathrm{C}$. PCR products were cleaned using a MultiScreenHTS PCRu96 filter plate (EMD Millipore) and quantified as above before pooling $20 \mathrm{ng}$ from each individual into a family pool. Then, fragments between 200 and $500 \mathrm{bp}$ were selected from this pool using a BluePippin instrument (Sage Science, Beverly, MA). Finally, fragments were submitted for multiplexed, 150-bp, single-end sequencing using the NextSeq500 platform (Illumina, San Diego, CA) at the Interdisciplinary Center for Biotechnology Research at the University of Florida (Gainesville). Subsequently, sequencing data were processed with the TASSEL-UNEAK nonreference genotyping by sequencing SNP calling pipeline (Lu et al., 2012) to produce a haplotype map (hap map) of the individuals with SNP loci identified. Loci with fewer than five tags per locus or more than $25 \%$ missing data were discarded. A genetic linkage map for this population is currently under construction (H.P Rodriguez-Armenta, personal communication). However, due to technical challenges in autotetraploid populations, it has not been completed. Although SHB is an autotetraploid [ $2 n=4 x=48$ (Qu et al., 1998)] and $V$. arboreum used for intersectional crosses is a colchicine-induced tetraploid (Lyrene and Olmstead, 2012), a $2 n$ ploidy level was used for the analyses due to unresolved technical challenges in autotetraploids (discussed in McCallum et al., 2012). The hapmap was used to estimate a kinship matrix based on genome-wide SNP data (Yang et al., 2010) in TASSEL version 5.2.13 (Bradbury et al., 2007). Then, the kinship matrix, hapmap, and phenotypic data were used to find marker-trait associations with RSA traits using a mixed linear model $(\mathrm{Yu}$ et al., 2006). Genetic $\left(\sigma_{\mathrm{G}}{ }^{2}\right)$ and residual variances $\left(\sigma_{\mathrm{R}}{ }^{2}\right)$ were used to compute the broad-sense heritability $\left(H^{2}\right)$ of each trait.
The genetic covariance between two traits $\left(\sigma_{\mathrm{G}(\mathrm{AB})}\right)$ was used to estimate the genetic correlation between them as previously done (Fita et al., 2006, 2008; Hebert et al., 1994; Lynch and Walsh, 1998). Where genetic correlations fell outside the range -1 to +1 (Hebert et al., 1994; Lynch and Walsh, 1998), they were considered nonestimable. SNP loci that exhibited statistically significant association (defined as $P \leq 10^{-3}$ after adjusting for multiple comparisons through the Bonferroni method) with heritable RSA traits (defined as $H^{2} \geq 0.10$ ) were termed candidate markers and used for in silico annotation.

The multiple sequence reads containing the SNP loci were aligned and consensus sequences ( $87 \mathrm{bp}$ ) were produced using STACKS (Catchen et al., 2013). These consensus sequences (Supplemental Table 4) were used as queries for homology search via Basic Local Alignment Search Tool [BLAST version 2.2.31 (Altschul et al., 1990)] in two custom-built databases created with root transcriptome contig sequences from SHB and $V$. arboreum from a previous study (J.W. Olmstead, unpublished data). Then, the sequence of the best BLAST match for each marker from the SHB transcriptome, or the $V$. arboreum transcriptome in absence of the former, was searched against the nonredundant protein database from NCBI (Pruitt

Table 2. Effects of family, substrate, and the interaction between family and substrate on dry weight of Vaccinium seedlings from five different families grown in bench-top rhizotrons for $77 \mathrm{~d}$.

\begin{tabular}{|c|c|c|c|c|}
\hline Family $^{z}$ & Substrate $^{\mathrm{y}}$ & $\begin{array}{l}\text { Root } \\
\text { dry wt } \\
(\mathrm{mg})^{\mathrm{x}}\end{array}$ & $\begin{array}{l}\text { Shoot } \\
\text { dry wt } \\
(\mathrm{mg})^{\mathrm{w}}\end{array}$ & $\begin{array}{c}\text { Whole } \\
\text { plant dry } \\
\text { wt (mg) }\end{array}$ \\
\hline $\mathrm{S} 1$ & & $175 \mathrm{~b}$ & 482 & 861 \\
\hline $\mathrm{S} 2$ & & $143 \mathrm{~b}$ & 462 & 853 \\
\hline S3 & & $300 \mathrm{a}$ & 362 & 581 \\
\hline S4 & & $200 \mathrm{ab}$ & 449 & 764 \\
\hline \multirow[t]{3}{*}{ S5 } & & $158 \mathrm{~b}$ & 479 & 1,186 \\
\hline & Peat & $236 \mathrm{a}$ & 592 & 1,100 \\
\hline & Peat:perlite & $155 \mathrm{~b}$ & 302 & 600 \\
\hline \multirow[t]{2}{*}{ S1 } & Peat & $217 \mathrm{a}$ & 628 & 1,117 \\
\hline & Peat:perlite & $134 \mathrm{a}$ & 337 & 606 \\
\hline \multirow[t]{2}{*}{ S2 } & Peat & $186 \mathrm{a}$ & 683 & 1,044 \\
\hline & Peat:perlite & $101 \mathrm{a}$ & 241 & 663 \\
\hline \multirow[t]{2}{*}{ S3 } & Peat & $230 \mathrm{~b}$ & 260 & 175 \\
\hline & Peat:perlite & $370 \mathrm{a}$ & 463 & 987 \\
\hline \multirow[t]{2}{*}{ S4 } & Peat & $324 \mathrm{a}$ & 675 & 1,310 \\
\hline & Peat:perlite & $77 \mathrm{~b}$ & 223 & 219 \\
\hline \multirow[t]{2}{*}{ S5 } & Peat & $224 \mathrm{a}$ & 714 & 1,852 \\
\hline & Peat:perlite & $93 \mathrm{~b}$ & 243 & 519 \\
\hline \multicolumn{5}{|l|}{$P$ value } \\
\hline Family & & 0.0024 & 0.5867 & 0.5917 \\
\hline Substrate & & 0.0025 & 0.2130 & 0.0583 \\
\hline Family $\times$ substrate & & 0.0003 & 0.1709 & 0.1359 \\
\hline
\end{tabular}

${ }^{\mathrm{z} F a m i l i e s ' ~ p e d i g r e e ~ i n f o r m a t i o n ~ c a n ~ b e ~ f o u n d ~ i n ~ T a b l e ~} 1$.

${ }^{y}$ Substrates were $100 \%$ peat or 3:1 peat:perlite.

${ }^{\mathrm{x}}$ Values shown are means of $\mathrm{n} \geq 7$ replications per family $\times$ substrate combination. Letters indicate significant differences $(P<0.05)$ among families, substrates, or substrates within a family as determined by post hoc Tukey honestly significant difference (HSD) tests.

"Values shown are means of $\mathrm{n}=4$ replications per family $\times$ substrate combination. Means were not significantly different among families, substrates, or substrates within a family as determined by post hoc Tukey HSD tests. 
et al., 2005) via BLASTX (Altschul et al., 1990) in Sept. 2015. A sequence was considered satisfactorily annotated if an alignment with e-value $\leq 10^{-4}$ and $30 \%$ or higher identity was produced over 30 or more amino acids. This percentage identity cutoff was selected bearing in mind that transcriptomebased query sequences - like the ones used here and in previous functional annotation efforts in blueberry (Gupta et al., 2015) can contain multiple transcripts, which lowers the percentage identity in alignments. Alignments with uncharacterized proteins were not considered satisfactory. Where satisfactory annotation was achieved, the description string of the best BLASTX match was adopted for the sequence, the GenBank identifier of the best match was listed, and the function of the protein was investigated in UniProtKB (The UniProt Consortium, 2015).

\section{Results}

SubSTRate EFFect. While neither family, substrate treatment, nor their interaction significantly affected whole plant or shoot dry weight (Table 2), all three of these factors significantly affected the root dry weight of Vaccinium species seedlings. On average, seedlings of family S3 had significantly larger root systems than seedlings in families S1, S2, and S5. The root systems of families S1, S2, S4, and S5 did not differ among themselves. Across families, peat-grown seedlings exhibited significantly greater root dry weight than peat: perlite-grown seedlings. The same effect was observed between peat-grown and peat:perlite-grown seedlings in families S4 and S5. The opposite effect was observed in family S3. Growth substrate did not affect root dry weight in families S1 and S2. Maximum root depth, SRL, root volume, average root diameter, total root length, total root surface area, and number of branching points were positively correlated with root dry weight $(P<0.001$ in all cases). Sub- Peat:perlite strate treatment significantly affected $P$ value RSA traits (Table 3). Peat-grown seedlings exhibited significantly lower maximum root depth and SRL than peat:perlite-grown seedlings. Additionally, peat-grown seedlings exhibited greater root volume and average root diameter than peat: perlite-grown seedlings. Peat-grown seedlings exhibited fewer first-order roots than peat:perlite-grown seedlings. Total root length, total root surface area, and the number of branching points were not significantly $\mathrm{P}$ affected by substrate treatment (data P2 not shown). In this experiment, the P3 average root system was $1.27 \mathrm{~m}$ long, P4 had a surface area of $385 \mathrm{~cm}^{2}$, and P5 contained 7511 branching points. P6

$\begin{array}{lrrrrr}\text { Root dry weight } & <0.0001 & 0.0005 & <0.0001 & 0.0001 & <0.0001 \\ \text { Substrate } & 0.0065 & 0.0382 & 0.0189 & 0.0420 & 0.0077 \\ \text { Family } \times \text { substrate } & 0.0582 & 0.0992 & 0.6947 & 0.3883 & 0.0078\end{array}$

${ }^{\mathrm{z}}$ Substrates were $100 \%$ peat or $3: 1$ peat:perlite.

'Values shown are means for each substrate after normalizing for root dry weight. Letters indicate significant differences $(P<0.05)$ as determined by post hoc Tukey honestly significant difference (HSD) tests.

Table 4. Effects of family pedigree on the dry weight of six families of Vaccinium seedlings grown in bench-top rhizotrons for $67 \mathrm{~d}$.

\begin{tabular}{lccc}
\hline Family $^{z}$ & ${\text { Root dry wt }(\mathrm{mg})^{\mathrm{y}}}^{\mathrm{P}}$ & Shoot dry wt $(\mathrm{mg})$ & Whole plant dry wt $(\mathrm{mg})$ \\
P2 & $48 \mathrm{~b}$ & $173 \mathrm{~b}$ & $221 \mathrm{~b}$ \\
P3 & $121 \mathrm{a}$ & $466 \mathrm{a}$ & $587 \mathrm{a}$ \\
P4 & $50 \mathrm{~b}$ & $198 \mathrm{~b}$ & $248 \mathrm{~b}$ \\
P5 & $71 \mathrm{~b}$ & $277 \mathrm{~b}$ & $348 \mathrm{~b}$ \\
P6 & $53 \mathrm{~b}$ & $221 \mathrm{~b}$ & $274 \mathrm{~b}$ \\
Palue & $66 \mathrm{~b}$ & $245 \mathrm{~b}$ & $311 \mathrm{~b}$ \\
Family pedigree & 0.0002 & $<0.0001$ & $<0.0001$
\end{tabular}

pedigree significantly affected root,
shoot, and whole plant dry weight

(Table 4). Seedlings in family P2 yalues shown are means of $\mathrm{n}=21$ replications per family. Letters indicate significant differences $(P<$ exhibited significantly higher biomass 0.05 ) as determined by post-hoc Tukey honestly significant difference (HSD) tests. 
Table 5. Effects of family pedigree on root system architecture traits of six families of Vaccinium seedlings grown in bench-top rhizotrons for $67 \mathrm{~d}$.

\begin{tabular}{|c|c|c|c|c|c|c|c|}
\hline Family $^{z}$ & $\begin{array}{l}\text { Maximum root } \\
\text { depth }(\mathrm{cm})^{\mathrm{y}}\end{array}$ & $\begin{array}{l}\text { Roots in the top } \\
8 \mathrm{~cm} \text { of soil }(\%)\end{array}$ & $\begin{array}{c}\text { Root } \\
\text { length }(\mathrm{cm})\end{array}$ & $\begin{array}{l}\text { Specific root } \\
\text { length }\left(\mathrm{m} \cdot \mathrm{g}^{-1}\right)\end{array}$ & $\begin{array}{c}\text { Branching } \\
\text { points }(\times 1,000)\end{array}$ & $\begin{array}{c}\text { First order } \\
\text { roots }(\times 1,000)\end{array}$ & $\begin{array}{l}\text { Avg root } \\
\text { diam }(\mathrm{mm})\end{array}$ \\
\hline $\mathrm{P} 1$ & $14.59 \mathrm{~b}$ & $58.97 \mathrm{ab}$ & $560.13 \mathrm{~b}$ & $81.53 \mathrm{bc}$ & $3.93 \mathrm{bc}$ & $2.67 \mathrm{dc}$ & $0.34 \mathrm{ab}$ \\
\hline $\mathrm{P} 2$ & $13.92 \mathrm{~b}$ & $71.06 \mathrm{a}$ & $309.49 \mathrm{c}$ & $62.38 \mathrm{c}$ & $2.58 \mathrm{c}$ & $1.76 \mathrm{~d}$ & $0.35 \mathrm{a}$ \\
\hline P4 & $26.30 \mathrm{a}$ & $25.94 \mathrm{~d}$ & $899.10 \mathrm{a}$ & $139.43 \mathrm{a}$ & $5.87 \mathrm{a}$ & $5.44 \mathrm{a}$ & $0.29 \mathrm{c}$ \\
\hline P5 & $21.18 \mathrm{a}$ & $48.43 \mathrm{abc}$ & $427.37 \mathrm{bc}$ & $95.32 \mathrm{abc}$ & $3.16 \mathrm{bc}$ & $2.80 \mathrm{dc}$ & $0.29 \mathrm{c}$ \\
\hline P6 & $22.77 \mathrm{a}$ & $38.77 \mathrm{bcd}$ & $656.32 \mathrm{~b}$ & $91.56 \mathrm{abc}$ & $4.34 \mathrm{ab}$ & $3.51 \mathrm{bc}$ & $0.30 \mathrm{bc}$ \\
\hline Root dry weight & $<0.0001$ & $<0.0001$ & $<0.0001$ & 0.1448 & $<0.0001$ & $<0.0001$ & 0.5796 \\
\hline Family & $<0.0001$ & $<0.0001$ & $<0.0001$ & $<0.0001$ & $<0.0001$ & $<0.0001$ & $<0.0001$ \\
\hline
\end{tabular}

${ }^{\text {zFamilies' pedigree information can be found in Table } 1 .}$

${ }^{y}$ Values shown are means for each family after normalizing for root dry weight. Letters indicate significant differences $(P<0.05)$ as determined by post hoc Tukey honestly significant difference (HSD) tests.

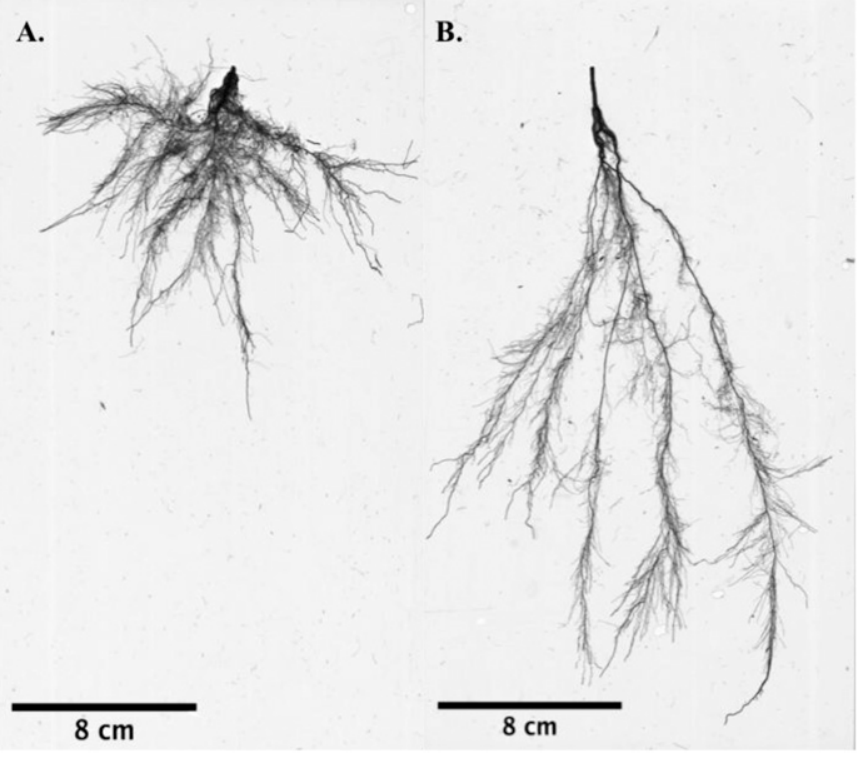

Fig. 2. Root system architecture of southern highbush blueberry [SHB (family P2)] and Vaccinium arboreum (family P3) seedlings grown in bench-top rhizotrons for $67 \mathrm{~d}$. Pedigree information for these families can be found in Table 1. (A) SHB root system: root dry weight $=67 \mathrm{mg}$, total root length $=$ $620 \mathrm{~cm}$. (B) V. arboreum root system: root dry weight $=69 \mathrm{mg}$, total root length $640 \mathrm{~cm}$. Root systems pictured to scale. Size bars represent $8 \mathrm{~cm}$.

Marker-trait association with RSA traits. A total of 3447 SNPs and eight RSA traits measured in 227 individuals resulting from a cross between a SHB cultivar and an interspecific hybrid between $\mathrm{SHB}$ and $V$. arboreum were used for the association study. All RSA traits except root length exhibited $H^{2}$ greater than 0.10 (Table 6). The $H^{2}$ of root length was $<0.01$. Genetic correlations between RSA traits ranged between -0.11 and 0.47 (Table 7 ). Genetic correlations with average root diameter were nonestimable (data not shown). A total of 57 significant marker-trait associations were found between 6 RSA traits and 54 markers (Table 6; Supplemental Table 4). Marker TP30609 was significantly associated with root surface area, root volume, number of branching points, and number of first-order roots. All other marker-trait associations were one to one. The proportion of phenotypic variation explained by markers ranged between $6.72 \%$ and $14.45 \%$. The sequences of 37 of the 54 markers exhibited significant homology with contigs in the SHB or $V$. arboreum root transcriptome (Table 8). Markers with no homology were not analyzed further. Markers TP10972, TP20147, TP2069, and TP5008 were found in the same contig in the SHB and $V$. arboreum transcriptome. All other markers had one-to-one matches. Median contig length was $501 \mathrm{bp}$. In the BLASTX search, 18 markers did not have significant or satisfactory matches and were not annotated. The neighboring regions of the 16 successfully annotated markers contained genes that code for proteins involved in ubiquitination (TP16403, TP16736, and TP17162), auxin response (TP53 and TP30062), and translation (TP12923), as well as proteins with functions as transcription factors (TP17298, TP17930, TP29772, TP33561, and TP7074), transmembrane transporters (TP5555), and enzymes (TP18501, TP22590, and TP283).

\section{Discussion}

RSA traits of cultivated SHB are attractive targets for developing MAS assays, as phenotypic characterization of below-ground traits cannot be accomplished without significant resources and/or destructive sampling. In this study, we developed an assay for RSA traits by testing for family-level differences among Vaccinium species. In particular, we sought to determine if differences in RSA traits could be quantified among various levels of introgression from $V$. arboreum into the SHB genetic background. This introgression of favorable RSA traits from $V$. arboreum has long been a goal in SHB breeding (Lyrene, 1997; Olmstead et al., 2013).

The RSA of Vaccinium species was affected by the substrate in which seedlings were grown. The greater root biomass in peat-grown seedlings compared with peat:perlite-grown seedlings supports previous studies on lowbush blueberry (Vaccinium angustifolium) and other crops demonstrating substrate effects on root biomass accumulation (Gioia et al., 2015; Hicklenton et al., 2000; Hund et al., 2009; Jin et al., 2015). Although peat-grown seedlings exhibited a tendency to have higher shoot and total dry weight than peat:perlite-grown seedlings, differences were not significant likely due to the limited number of replications used in Expt. 1. Root dry weight was positively correlated with most traits, in agreement with previous studies (Fita et al., 2008; Johnson et al., 2000; Khan et al., 2012). However, substrate treatments affected RSA beyond the effect on biomass accumulation. The thicker roots of peat-grown compared with peat-perlite-grown plants led to 
significant differences in the total root Table 6 . Single nucleotide polymorphism markers with statistically significant association $\left(P \leq 10^{-3}\right)$ volume. In addition, peat-grown plants had fewer first-order roots than peat: perlite-grown ones. Considering that the SRL of first-order roots is higher than the SRL of higher order roots in Vaccinium species (Valenzuela-Estrada et al., 2008), the lower abundance of first-order roots in peat-grown plants compared with peat:perlite-grown ones explains the lower SRL of seedlings in the former treatment. Although high SRL has been associated with growth in low-fertility soils (Eissenstat, 1992; Ostonen et al., 2007), the hydraulic and nutritional characteristics of the substrates used in this experiment were not measured. Hence, conclusions cannot be drawn about specific substrate characteristics affecting SRL in Vaccinium species.

In light of our finding that roots of peat-grown seedlings had greater average diameter than peat:perlitegrown ones, assuming that thicker roots can withstand cleanup better than thin ones, and considering that flushing peat away from the root was easier than flushing peat:perlite, peat was selected as the substrate for subsequent RSA studies and scanning procedures and image acquisition parameters were adjusted (as noted in the Materials and Methods section).

Comparisons among families revealed significant differences in root, shoot, and whole plant dry weight. Seedlings in family P2 were the result of a cross between advanced selections from the University of Florida blueberry breeding program and they were bigger than seedlings in all other families in Expt. 2. This is consistent with plant vigor being one of the standards used for phenotypic selection the breeding program (Lyrene, 2007). Families also differed on their RSA. The shallower roots and greater percentage of roots close to the surface in SHB seedlings (family P2) compared with $V$. arboreum seedlings (family $\mathrm{P} 3$ ) are the first set of empirical evidence documenting RSA differences between plants in these two taxa grown Maximum root under the same conditions. These re- depth $(\mathrm{cm})$ sults are in agreement with previous Root surface area $\left(\mathrm{cm}^{2}\right)$ reports based on field observations Average root (Lyrene, 1991; Lyrene and Brooks, 1995). Water acquisition from subsoil diameter ( $\mathrm{mm})$

\begin{tabular}{|c|c|c|c|c|c|c|}
\hline Trait & Mean & Range & $H^{2 \mathrm{z}}$ & Marker & $R^{2}$ & $P$ value $^{y}$ \\
\hline \multirow{50}{*}{$\begin{array}{l}\text { Roots in the top } \\
8 \mathrm{~cm} \text { of soil }(\%)\end{array}$} & \multirow[t]{50}{*}{32.42} & \multirow[t]{50}{*}{$10-90$} & \multirow[t]{50}{*}{0.36} & TP10972 & 0.0941 & $<0.0001$ \\
\hline & & & & TP12275 & 0.0851 & $<0.0001$ \\
\hline & & & & TP1255 & 0.0858 & $<0.0001$ \\
\hline & & & & TP12923 & 0.0853 & $<0.0001$ \\
\hline & & & & ТР14807 & 0.0882 & $<0.0001$ \\
\hline & & & & ТР15079 & 0.0878 & $<0.0001$ \\
\hline & & & & ТР16401 & 0.0866 & $<0.0001$ \\
\hline & & & & ТР16403 & 0.1007 & $<0.0001$ \\
\hline & & & & ТР16736 & 0.0852 & $<0.0001$ \\
\hline & & & & ТP171 & 0.0930 & $<0.0001$ \\
\hline & & & & TP17162 & 0.0970 & 0.0001 \\
\hline & & & & ТР17244 & 0.0876 & $<0.0001$ \\
\hline & & & & ТP17298 & 0.0849 & $<0.0001$ \\
\hline & & & & ТP17930 & 0.0858 & $<0.0001$ \\
\hline & & & & TP18062 & 0.0888 & 0.0001 \\
\hline & & & & ТP18501 & 0.0849 & $<0.0001$ \\
\hline & & & & ТР18747 & 0.0849 & $<0.0001$ \\
\hline & & & & ТP1952 & 0.0903 & $<0.0001$ \\
\hline & & & & TP20147 & 0.0855 & $<0.0001$ \\
\hline & & & & ТР2069 & 0.1000 & 0.0002 \\
\hline & & & & TP2117 & 0.0852 & $<0.0001$ \\
\hline & & & & TP2155 & 0.0864 & $<0.0001$ \\
\hline & & & & TP21868 & 0.1169 & $<0.0001$ \\
\hline & & & & ТР22519 & 0.0852 & $<0.0001$ \\
\hline & & & & ТР22590 & 0.0882 & $<0.0001$ \\
\hline & & & & ТР23301 & 0.0851 & 0.0001 \\
\hline & & & & ТР23574 & 0.0920 & $<0.0001$ \\
\hline & & & & ТР25121 & 0.0672 & 0.0009 \\
\hline & & & & ТР25656 & 0.1445 & $<0.0001$ \\
\hline & & & & ТР26551 & 0.0929 & $<0.0001$ \\
\hline & & & & ТP283 & 0.0867 & $<0.0001$ \\
\hline & & & & ТР28439 & 0.0857 & $<0.0001$ \\
\hline & & & & ТP29772 & 0.0677 & 0.0004 \\
\hline & & & & ТР30062 & 0.0896 & $<0.0001$ \\
\hline & & & & TP30258 & 0.0854 & $<0.0001$ \\
\hline & & & & ТP33561 & 0.0875 & $<0.0001$ \\
\hline & & & & ТР4589 & 0.0853 & $<0.0001$ \\
\hline & & & & ТР4941 & 0.0854 & 0.0001 \\
\hline & & & & TP5008 & 0.0885 & $<0.0001$ \\
\hline & & & & TP5072 & 0.0858 & $<0.0001$ \\
\hline & & & & TP5246 & 0.0852 & $<0.0001$ \\
\hline & & & & TP53 & 0.0935 & 0.0001 \\
\hline & & & & TP5555 & 0.0849 & $<0.0001$ \\
\hline & & & & TP5627 & 0.0899 & $<0.0001$ \\
\hline & & & & ТP5668 & 0.0867 & $<0.0001$ \\
\hline & & & & ТР702 & 0.0867 & $<0.0001$ \\
\hline & & & & ТР7074 & 0.0955 & $<0.0001$ \\
\hline & & & & ТР8034 & 0.0855 & $<0.0001$ \\
\hline & & & & ТР9464 & 0.0903 & $<0.0001$ \\
\hline & & & & TP9982 & 0.0849 & 0.0006 \\
\hline $\begin{array}{l}\text { Maximum root } \\
\text { depth }(\mathrm{cm})\end{array}$ & 26.41 & $3.7-37.2$ & 0.33 & None found & & \\
\hline Root surface area $\left(\mathrm{cm}^{2}\right)$ & 400.46 & 36.46-999.73 & 0.17 & TP30609 & 0.085 & $<0.0001$ \\
\hline Average root & 0.26 & $0.20-0.39$ & 0.25 & TP14326 & 0.083 & $<0.0001$ \\
\hline diameter (mm) & & & & ТP16027 & 0.084 & $<0.0001$ \\
\hline & & & & ТР26072 & 0.074 & $<0.0001$ \\
\hline
\end{tabular}

with heritable root system architecture traits in an interspecific pseudo-backcross family between southern highbush blueberry and Vaccinium arboreum. 
Table 6. Continued.

\begin{tabular}{lrccccc}
\hline Trait & Mean & Range & $H^{2 \mathrm{z}}$ & Marker & $R^{2}$ & $P$ value \\
\hline Root volume $\left(\mathrm{cm}^{3}\right)$ & 2.64 & $0.22-8.08$ & 0.30 & TP30609 & 0.071 & $<0.0001$ \\
First order roots $(\times 1000)$ & 24.17 & $3.23-44.16$ & 0.25 & TP30609 & 0.102 & $<0.0001$
\end{tabular}

${ }^{\mathrm{z}}$ Broad-sense heritability.

${ }^{\mathrm{y}}$ Adjusted for multiple comparisons with the Bonferroni method.

Table 7. Genetic correlations between root system architecture traits in an interspecific pseudobackcross family between southern highbush blueberry and Vaccinium arboreum.

\begin{tabular}{lcrrrrrr}
\hline Root system architecture traits & T1 & \multicolumn{1}{c}{ T2 } & \multicolumn{1}{c}{ T3 } & \multicolumn{1}{c}{ T4 } & \multicolumn{1}{c}{ T5 } & \multicolumn{1}{c}{ T6 } & T7 \\
\hline Roots in the top 8 cm of soil [T1 $(\%)]$ & 1.00 & -0.03 & -0.02 & 0.00 & -0.11 & -0.01 & 0.00 \\
Maximum root depth [T2 $(\mathrm{cm})]$ & & 1.00 & -0.02 & 0.01 & 0.47 & -0.01 & 0.00 \\
Total root length [T3 $(\mathrm{cm})]$ & & & 1.00 & 0.11 & -0.02 & -0.01 & 0.00 \\
Root surface area [T4 $\left.\left(\mathrm{cm}^{2}\right)\right]$ & & & & 1.00 & 0.38 & 0.00 & 0.00 \\
Root volume [T5 $\left.\left(\mathrm{cm}^{3}\right)\right]$ & & & & 1.00 & 0.00 & 0.00 \\
First-order roots [T6 $(\times 1,000)]$ & & & & & & 1.00 & 0.00 \\
Branching points [T7 $(\times 1,000)]$ & & & & & & 1.00 \\
\hline
\end{tabular}

drought-tolerance of $V$. arboreum plants (Stockton, 1976). Additionally, deeper roots would give $V$. arboreum access to nitrate that has percolated to deeper parts of the soil (Lynch and Wojciechowski, 2015), which combined with its greater nitrate reductase activity (Poonnachit and Darnell, 2004), could explain the soil nitrogen adaptation of this plant species. Finally, while soil acidity and high aluminum concentrations at greater soil depths are challenges to deep root production in other plant species (Lynch and Wojciechowski, 2015), $V$. arboreum and its offspring would be particularly well adapted for growth at greater depths due to their preference for acidic soils (Finn et al., 1993) and mycorrhizae-mediated aluminum toxicity tolerance (Yang and Goulart, 2000). Altogether, our results suggest that $V$. arboreum could be a source of greater root depth in SHB breeding programs.

Families with different levels of $V$. arboreum introgressions exhibited midrange phenotypes between the RSA of families $\mathrm{P} 2$ and P3, with the exception of family P4, which exhibited accentuated $V$. arboreum-like RSA. The finding that families with $V$. arboreum parentage in the three preceding generations exhibit $V$. arboreum-like root depth and SRL suggests that RSA traits are heritable. The root architecture of family $\mathrm{P} 4 \mathrm{might}$ have been caused by a combination of the root depth and high SRL alleles from its two different $V$. arboreum grandparents, as this family is the product of the cross of two interspecific F1 hybrids between SHB and $V$. arboreum. Altogether, these results provide evidence of differences in RSA traits among families of Vaccinium species and highlight the opportunity to use $V$. arboreum as a genetic source for SHB breeding.

Except for root length, all RSA traits studied in the pseudobackcross family exhibited moderate to low broad-sense heritabilities that fall within the range found for RSA traits in seedlings of other species (Fita et al., 2008; Hamada et al., 2012; Khan et al., 2012). This supports the conclusion from Expt. 2 that both maximum root depth and root distribution in the top soil layer are heritable in Vaccinium species. However, future work will be necessary to extend these results beyond the growth conditions used in this study. RSA traits exhibited moderate to low genetic correlations among them, which fall within the range published for RSA traits in other species (Fita et al., 2006, 2008). In the present study and in previous research
(Hebert et al., 1994), some genetic correlations exhibited magnitudes outside of theoretical limits, likely due to the use of an indirect estimation method and a single family in a single environment as discussed in Lynch and Walsh (1998) and references therein.

All but one of the heritable RSA traits were significantly associated with at least one marker. While there were not any markers associated with maximum root depth, the majority of the associations were with the percentage of roots in the top $8 \mathrm{~cm}$ of soil. Hence, MAS against these alleles may lead to Vaccinium species

1.00 plants with greater percentages of roots in deeper soil strata. Across all heritable RSA traits, marker effects were small, but some traits were associated with more than one marker. This suggests that several small effects could be stacked to breed for an RSA ideotype, as previously done in other crops (Liu et al., 2012; Steele et al., 2006). Moreover, this further emphasizes the quantitative nature of RSA traits (Johnson et al., 2000). In previous studies, several QTL that affect RSA traits have been discovered in other plant species (Fita et al., 2008; Hamada et al., 2012; Johnson et al., 2000; Li et al., 2015; Ron et al., 2013; Steele et al., 2006), which suggests that QTL that affect RSA could exist in SHB. Nevertheless, in absence of a genetic map that includes the markers used here, we were unable to test this hypothesis.

Instead, we pursued a two-step annotation process analogous to the candidate gene mining efforts undertaken in model organisms (Liu et al., 2012; Monclus et al., 2012). First, due to the short sequences produced by the genotyping by sequencing pipeline for each polymorphism, we gathered the sequence of the regions neighboring significantly associated markers in the available Vaccinium species root transcriptomes. Then, we annotated these regions based on protein homology. Only 19 of the 54 markers were successfully annotated. The remaining markers were either not represented in the SHB or $V$. arboreum transcriptome or they did not have satisfactory matches in the NCBI database. Markers not present in the transcriptome are potentially intronic. Lack of significant homology with databases was likely caused by the short transcriptome sequences used as queries.

The annotation resulted in several genomic regions that affect RSA traits. Among these, sequence homologies to genes involved in root development in other species were identified. For instance, the peptides neighboring TP53 and TP30062 exhibited homology with proteins involved in auxin-dependent gene expression (Ellis et al., 2005) and polar auxin transport (Lin and Wang, 2005), respectively; which have been found to have an effect in root development in Arabidopsis thaliana (Liu et al., 2014). Similarly, the peptide neighboring TP29772 has homology with transcription factor STOP1, which controls root-level responses to proton and aluminum toxicity in A. thaliana (Iuchi et al., 2007). Although the functions of the peptides in the neighboring region of other significantly associated markers did not expose direct relationships to RSA traits, all the annotated genes constitute targets for future studies in Vaccinium species and beyond. 
Table 8. In silico annotation based on protein homology with the NCBI GenBank database of the transcribed regions neighboring markers significantly associated with root system architecture traits in an interspecific pseudo-backcross family between southern highbush blueberry and Vaccinium arboreum.

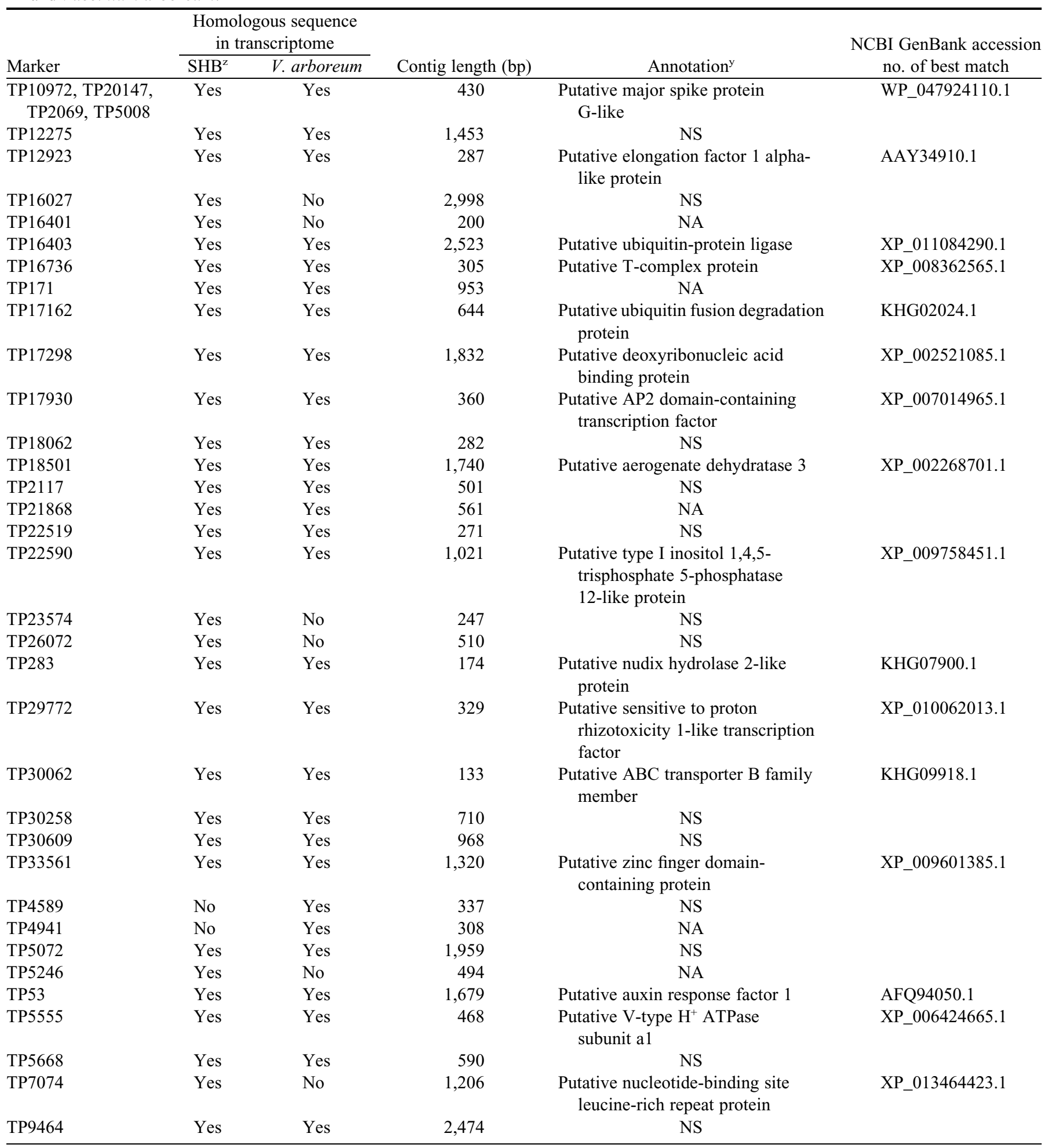

$\mathrm{NA}=$ no significant similarity found; NS = alignment found with uncharacterized proteins.

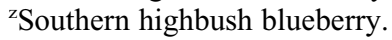

${ }^{y}$ Description string of the best BLASTX match (e-value $\leq 10^{-4}$ and $30 \%$ or higher identity) in NCBI GenBank.

An area that warrants further investigation is the relationship between the RSA of seedlings and adult plants, and seedlings and plants with adventitious roots. Previous studies have found that RSA differences and genetic architecture are consistent between seedlings and mature plants in other species (Dias et al., 2004; Fita et al., 2006), but studies in Vaccinium species 
are not available. Nevertheless, candidate genes associated with RSA in Vaccinium species seedlings were homologous to genes that impact root phenotypes of mature specimens of $A$. thaliana. This suggests that the plant breeding tools developed here are based on plant physiological processes that affect the RSA of plants across growth stages. RSA differences between seedlings and rooted cuttings have been described in other species, including lowbush blueberry (Morrison et al., 2000). Yet, to the best of our knowledge, there have not been studies focusing on the genetic elements controlling seminal and adventitious RSA in SHB or other Vaccinium species. Further investigation on this subject will be requisite considering that commercial propagation of SHB is done through rooted cuttings or in vitro methods (Lyrene, 2007).

Altogether, the present study identified a growth medium for root phenotyping of thin-rooted Vaccinium species. Additionally, root depth differences between SHB and $V$. arboreum grown under the same conditions were found. This trait is of interest for SHB breeding as it may impact drought tolerance, access to nutrients, and soil adaptation. The intermediate RSA of interspecific hybrid seedlings between SHB and $V$. arboreum, and the non-zero heritability estimates for RSA traits in an interspecific pseudo-backcross family suggest that breeding for RSA traits in SHB is feasible. SNP markers significantly associated with RSA traits highlight the possibility of employing MAS for this means. In silico annotation of the transcribed regions neighboring these markers identified biologically relevant genomic regions that affect RSA in Vaccinium species and other plants suggesting that these markers may be a robust tool for breeding for RSA traits.

\section{Literature Cited}

Altschul, S.F., W. Gish, W. Miller, E.W. Myers, and D.J. Lipman. 1990. Basic local alignment search tool. J. Mol. Biol. 215:403-410. Bhakta, M.S., V.A. Jones, and C.E. Vallejos. 2015. Punctuated distribution of recombination hotspots and demarcation of pericentromeric regions in Phaseolus vulgaris L. PLoS One 10:e116822.

Bouma, T.J., K.L. Nielsen, and B. Koutstaal. 2000. Sample preparation and scanning protocol for computerized analysis of root length and diameter. Plant Soil 218:185-196.

Bradbury, P.J., Z. Zhang, D.E. Kroon, T.M. Casstevens, Y. Ramdoss, and E.S. Buckler. 2007. TASSEL: Software for association mapping of complex traits in diverse samples. Bioinformatics 23:2633-2635.

Brevis, P.A., N.V. Bassil, J.R. Ballington, and J.F. Hancock. 2008. Impact of wide hybridization on highbush blueberry breeding. J. Amer. Soc. Hort. Sci. 133:427-437.

Bryla, D.R. and B.C. Strik. 2007. Effects of cultivar and plant spacing on the seasonal water requirements of highbush blueberry. J. Amer. Soc. Hort. Sci. 132:270-277.

Catchen, J., P. Hohenlohe, S. Bassham, A. Amores, and W. Cresko. 2013. Stacks: An analysis tool set for population genomics. Mol. Ecol. 22:3124-3140.

Coville, F.V. 1910. Experiments in blueberry culture. U.S. Dept. Agr. Bul. 193.

Dias, R.C.S., B. Picó, A. Espinos, and F. Nuez. 2004. Resistance to melon vine decline derived from Cucumis melo ssp. agrestis: Genetic analysis of root structure and root response. Plant Breed. 123:66-72.

Eissenstat, D.M. 1992. Costs and benefits of constructing roots of small diameter. J. Plant Nutr. 15:763-782.

Ellis, C.M., P. Nagpal, J.C. Young, G. Hagen, T.J. Guilfoyle, and J.W. Reed. 2005. Auxin response factor1 and auxin response factor 2 regulate senescence and floral organ abscission in Arabidopsis thaliana. Development 132:4563-4574.
Finn, C.E., J. Luby, C.J. Rosen, and P. Ascher. 1993. Blueberry germplasm screening at several soil $\mathrm{pH}$ regimes: I Plant survival and growth. J. Amer. Soc. Hort. Sci. 118:377-382.

Fita, A., B. Picó, A.J. Monforte, and F. Nuez. 2008. Genetics of root system architecture using near-isogenic lines of melon. J. Amer. Soc. Hort. Sci. 133:448-458.

Fita, A., B. Picó, and F. Nuez. 2006. Implications of the genetics of root structure in melon breeding. J. Amer. Soc. Hort. Sci. 131:372379.

Gastal, F. and G. Lemaire. 2002. N uptake and distribution in crops: An agronomical and ecophysiological perspective. J. Expt. Bot. 53:789799.

Gioia, T., K.A. Nagel, R. Beleggia, M. Fragasso, D.B.M. Ficco, R. Pieruschka, P. De Vita, F. Fiorani, and R. Papa. 2015. Impact of domestication on the phenotypic architecture of durum wheat under contrasting nitrogen fertilization. J. Expt. Bot. 66:5519-5530.

Gupta, V., A.D. Estrada, I. Blakley, R. Reid, K. Patel, M.D. Meyer, S. Uggerhøj Andersen, A.F. Brown, M.A. Lila, and A.E. Loraine. 2015. RNA-Seq analysis and annotation of a draft blueberry genome assembly identifies candidate genes involved in fruit ripening, biosynthesis of bioactive compounds, and stage-specific alternative splicing. Gigascience 4-5:1-22.

Hamada, A., M. Nitta, S. Nasuda, K. Kato, M. Fujita, H. Matsunaka, and Y. Okumoto. 2012. Novel QTLs for growth angle of seminal roots in wheat (Triticum aestivum L.). Plant Soil 354:395-405.

Hebert, D., S. Faure, and I. Olvieri. 1994. Genotypic, phenotypic, and environmental correlations in black medic Medicago lupine L. grown in three different environments. Theor. Appl. Genet. 88:604-613.

Henry, A., A.J. Cal, T.C. Batoto, R.O. Torres, and R. Serraj. 2012. Root attributes affecting water uptake of rice (Oryza sativa) under drought. J. Expt. Bot. 63:4751-4763.

Hicklenton, P.R., J.Y. Reekie, and R.J. Gordon. 2000. Physiological and morphological traits of lowbush blueberry (Vaccinium angustifolium Ait.) plants in relation to post-transplant conditions and water availability. Can. J. Plant Sci. 80:861-867.

Hund, A., N. Ruta, and M. Liedgens. 2009. Rooting depth and water use efficiency of tropical maize inbred lines, differing in drought tolerance. Plant Soil 318:311-325.

Iuchi, S., H. Koyama, A. Iuchi, Y. Kobayashi, S. Kitabayashi, Y. Kobayashi, T. Ikka, T. Hirayama, K. Shinozaki, and M. Kobayashi. 2007. Zinc finger protein STOP1 is critical for proton tolerance in arabidopsis and coregulates a key gene in aluminum tolerance. Proc. Natl. Acad. Sci. USA 104:9900-9905.

Jin, C.W., Y.Q. Ye, and S.J. Zheng. 2015. An underground tale: Contribution of microbial activity to plant iron acquisition via ecological processes. Ann. Bot. 114:7-18.

Johnson, W.C., L.E. Jackson, O. Ochoa, R. van Wijk, J. Peleman, D.A. St. Clair, and R.W. Michelmore. 2000. Lettuce, a shallow-rooted crop, and Lactuca serriola, its wild progenitor, differ at QTL determining root architecture and deep soil water exploitation. Theor. Appl. Genet. 101:1066-1073.

Khan, N., R. Kazmi, L. Willems, A. van Heusden, W. Ligterink, and H. Hilhorst. 2012. Exploring the natural variation for seedling traits and their link with seed dimensions in tomato. PLoS One $7: 1-22$.

King, J., A. Gay, R. Sylvester-Bradley, I. Bingham, J. Foulkes, P. Gregory, and D. Robinson. 2003. Modeling cereal root systems for water and nitrogen capture: Towards an economic optimum. Ann. Bot. 91:383-390.

Kuijken, R.C.P., F.A. van Eeuwijk, L.F.M. Marcelis, and H.J. Bouwmeester. 2015. Root phenotyping: From component trait in the lab to breeding. J. Expt. Bot. 66:5389-5401.

Lambers, H., E. Martinoia, and M. Renton. 2015. Plant adaptations to severely phosphorus-impoverished soils. Curr. Opin. Plant Biol. 25:23-31.

Li, J., Y. Han, L. Liu, Y. Chen, Y. Du, J. Zhang, H. Sun, and Q. Zhao. 2015. qRT9, a quantitative trait locus controlling root thickness and root length in upland rice. J. Expt. Bot. 66:2723-2732. 
Lin, R. and H. Wang. 2005. Two homologous ATP-binding cassette transporter proteins, AtMDR1 and AtPGP1, regulate arabidopsis photomorphogenesis and root development by mediating polar auxin transport. Plant Physiol. 138:949-964.

Liu, J., J. Row, and K. Lindsey. 2014. Hormonal crosstalk for root development: A combined experimental and modeling perspective. Front. Plant Sci. 5:1-8.

Liu, R., H. Zhang, P. Zhao, Z. Zhang, W. Liang, Z. Tian, and Y. Zheng. 2012. Mining of candidate maize genes for nitrogen use efficiency by integrating gene expression and QTL data. Plant Mol. Biol. Rpt. 30:297-308.

Lu, F., J. Glaubitz, H. Harriman, T. Casstevens, and R. Elshire. 2012. TASSEL 3.0 Universal Network Enabled Analysis Kit Pipeline Documentation. 26 Oct. 2015. <https://bytebucket.org/tasseladmin/ tassel-5-source/wiki/docs/TasselPipelineUNEAK.pdf $>$.

Lynch, J.P. and T. Wojciechowski. 2015. Opportunities and challenges in the subsoil: Pathways to deeper rooted crops. J. Expt. Bot. 66: 2199-2210.

Lynch, M. and B. Walsh. 1998. Genetics and analysis of quantitative traits. Sinauer Assoc., Sunderland, MA.

Lyrene, P. 2007. Breeding southern highbush blueberries. Plant Breed. Rev. 30:353-414.

Lyrene, P.M. 1991. Fertile derivatives from sparkleberry x blueberry crosses. J. Amer. Soc. Hort. Sci. 116:899-902.

Lyrene, P.M. 1997. Value of various taxa in breeding tetraploid blueberries in Florida. Euphytica 94:15-22.

Lyrene, P.M. and S.J. Brooks. 1995. Use of sparkleberry in breeding highbush blueberry cultivars, p. 29-38. In: R.E. Gough and R.F. Korcak (eds.). Blueberries: A century of research. Food Products Press, Binghamton, NY.

Lyrene, P.M. and J.W. Olmstead. 2012. The use of inter-sectional hybrids in blueberry breeding. Intl. J. Fruit Sci. 12:269-275.

McCallum, S., M. Woodhead, L. Jorgensen, S. Gordon, R. Brennan, J. Graham, C.A. Hackett, L.J. Rowland, J.F. Hancock, J.W. Olmstead, and N.V. Bassil. 2012. Developing tools for long-term breeding of blueberry germplasm for UK production. Intl. J. Fruit Sci. 12:294 303.

Monclus, R., J.C. Leplé, C. Bastien, P.F. Bert, M. Villar, N. Marron, F. Brignolas, and V. Jorge. 2012. Integrating genome annotation and QTL position to identify candidate genes for productivity, architecture and water-use efficiency in Populus spp. BMC Plant Biol. 12:1-15.

Moore, J.N. 1965. Improving highbush blueberries by breeding and selection. Euphytica 14:39-48.

Morrison, S., J.M. Smagula, and W. Litten. 2000. Morphology, growth, and rhizome development of Vaccinium angustifolium Ait. seedlings, rooted softwood cuttings, and micropropagated plantlets. HortScience 35:738-741.

Nagel, K.A., D. Bonnet, R. Furbank, A. Walter, U. Schurr, and M. Watt. 2015. Simultaneous effects of leaf irradiance and soil moisture on growth and root system architecture of novel wheat genotypes: Implications for phenotyping. J. Expt. Bot. 66:5441-5452.

Olmstead, J.W., H.P. Rodriguez-Armenta, and P.M. Lyrene. 2013. Using sparkleberry as a genetic source for machine harvest traits for southern highbush blueberry. HortTechnology 23:419-424.

Ostonen, I., U. Püttsepp, C. Biel, O. Alberton, M.R. Bakker, K. Lõmus, H. Majdi, S. Metcalfe, A.F.M. Olsthoorn, A. Pronk, E. Vanguelova, M. Weih, and I. Brunner. 2007. Specific root length as an indicator of environmental change. Plant Biosyst. 141:426-442.
Padilla, F.M. and F.I. Pugnaire. 2007. Rooting depth and soil moisture control Mediterranean woody seedling survival during drought. Funct. Ecol. 21:489-495.

Pinheiro, H.A., F.M. DaMatta, A.R.M. Chaves, M.E. Loureriro, and C. Ducatti. 2005. Drought tolerance is associated with rooting depth and stomatal control of water use in clones of Coffea canephora. Ann. Bot. 96:101-108.

Poonnachit, U. and R.L. Darnell. 2004. Effect of ammonium and nitrate on ferric chelate reductase and nitrate reductase in Vaccinium species. Ann. Bot. 93:399-405.

Pritts, M. and J. Hancock. 1992. Highbush blueberry production guide. Northeast Reg. Agr. Eng. Serv., Ithaca, NY.

Pruitt, K.D., T. Tatusova, and D.R. Maglott. 2005. NCBI Reference Sequence (RefSeq): A curated non-redundant sequence database of genomes, transcripts and proteins. Nucleic Acids Res. 33:D501D504.

Qu, L., J.F. Hancock, and J.H. Whallon. 1998. Evolution in an autopolyploid group displaying predominantly bivalent pairing at meiosis: Genomic similarity of diploid Vaccinium darrowii and autotetraploid $V$. corymbosum (Ericaceae). Amer. J. Bot. 85:698-703.

Ron, M., M.W. Dorrity, M. de Lucas, T. Toal, R.I. Hernandez, S.A. Litlle, J.N. Maloof, D.J. Kliebenstein, and S.M. Brady. 2013. Identification of novel loci regulating interspecific variation in root morphology and cellular development in tomato. Plant Physiol. 162:755-768.

Steele, K.A., A.H. Price, H.E. Shashidhar, and J.R. Witcombe. 2006. Marker-assisted selection to introgress rice QTLs controlling root traits into an Indian upland rice variety. Theor. Appl. Genet. 112: 208-221.

Stockton, L.A., Jr. 1976. Propagation and autecology of Vaccinium arboreum and its graft compatibility with Vaccinium ashei. MS Thesis, Texas A\&M Univ., College Station.

The UniProt Consortium. 2015. UniProt: A hub for protein information. Nucleic Acids Res. 43:D204-D212.

Valenzuela-Estrada, L.R., V. Vera-Carballo, L.E. Ruth, and D.M. Eissenstat. 2008. Root anatomy, morphology and longevity among root orders in Vaccinium corymbosum (Ericaceae). Amer. J. Bot. 95:1506-1514.

Williamson, J.G., J.W. Olmstead, and P.M. Lyrene. 2015. Florida's commercial blueberry industry. Univ. Florida, Dept. Hort. Sci. Dept., Inst. Food Agr. Sci. Ext. HS742.

Yang, J., B. Benyamin, B.P. McEvoy, S. Gordon, A.K. Henders, D.R. Nyholt, P.A. Madden, A.C. Heath, N.G. Martin, G.W. Montgomery, M.E. Goddard, and P.M. Visscher. 2010. Common SNPs explain a large proportion of heritability for human height. Nat. Genet. 42:565-569.

Yang, W. and B. Goulart. 2000. Mycorrhizal infection reduces shortterm aluminum uptake and increases root cation exchange capacity of highbush blueberry plants. HortScience 35:1083-1086.

York, L.M., T. Galindo-Castañeda, J.R. Schussler, and J.P. Lynch. 2015. Evolution of U.S. maize (Zea mays L.) root architectural and anatomical phenes over the past 100 years corresponds to increased tolerance of nitrogen stress. J. Expt. Bot. 66:2347-2358.

Yu, J., G. Pressoir, W.H. Briggs, I.V. Bi, M. Yamasaki, J.F. Doebley, M.D. McMullen, B.S. Gaut, D.M. Nielsen, J.B. Holland, S. Kresovich, and E. Buckler. 2006. A unified mixed-model method for association mapping that accounts for multiple levels of relatedness. Nat. Genet. 38:203-208. 
Supplemental Table 1. Sequences of common adapters used in library construction for genotyping by sequence of an interspecific pseudobackcross family between southern highbush blueberry and $V$. arboreum.

\begin{tabular}{lc}
\hline Primer name & \multicolumn{1}{c}{ Sequence (5' to 3') } \\
\hline Com_F & AGA TCG GAA GAG CGG TTC AGC AGG AAT \\
& GCC GAG \\
Com_R & CTC GGC ATT CCT GCT GAA CCG CTC TTC \\
& CGA TCT TGC A \\
\hline
\end{tabular}

Supplemental Table 2. Sequences of common primers used in library construction for genotyping by sequence of an interspecific pseudobackcross family between southern highbush blueberry and $V$. arboreum.

\begin{tabular}{lc}
\hline Primer name & Sequence (5' to 3') \\
\hline PstI_F & ACA CTC TTT CCC TAC ACG ACG CTC TTC \\
& CGA TCT CTC CAT GCA \\
PstI_R & TGG AGA GAT CGG AAG AGC GTC GTG TAG \\
& GGA AAG AGT GT \\
\hline
\end{tabular}

Supplemental Table 3. Barcode sequences used for multiplexed library construction for genotyping by sequence of an interspecific pseudobackcross family between southern highbush blueberry and $V$. arboreum.

\begin{tabular}{|c|c|c|c|}
\hline Barcode & Sequence $\left(5^{\prime}\right.$ to $\left.3^{\prime}\right)$ & Barcode & Sequence $\left(5^{\prime}\right.$ to $\left.3^{\prime}\right)$ \\
\hline A01.F & CTCC & E01.F & CTATTA \\
\hline A02.F & TGCA & $\mathrm{E} 02 . \mathrm{F}$ & GCCAGT \\
\hline A03.F & ACTA & E03.F & GGAAGA \\
\hline A04.F & CAGA & E04.F & GTACTT \\
\hline A05.F & $\mathrm{AACT}$ & E05.F & GTTGAA \\
\hline A06.F & GCGT & E06.F & TAACGA \\
\hline A07.F & CGAT & E07.F & TGGCTA \\
\hline A08.F & GTAA & E08.F & TATTTTT \\
\hline A09.F & AGGC & E09.F & CTTGCTT \\
\hline A10.F & GATC & E10.F & ATGAAAC \\
\hline A11.F & TCAC & E11.F & AAAAGTT \\
\hline A12.F & TGCGA & E12.F & GAATTCA \\
\hline B01.F & CGCTT & F01.F & GAACTTC \\
\hline B02.F & TCACC & F02.F & GGACCTA \\
\hline B03.F & CTAGC & F03.F & GTCGATT \\
\hline B04.F & ACAAA & F04.F & AACGCCT \\
\hline B05.F & TTCTC & F05.F & AATTGCA \\
\hline B06.F & AGCCC & F06.F & ACGTGTT \\
\hline B07.F & GTATT & F07.F & ATTAATT \\
\hline B08.F & CTGTA & F08.F & ATTGGAT \\
\hline B09.F & ACCGT & F09.F & CATAAGT \\
\hline B10.F & GCTTA & F10.F & CGCTGAT \\
\hline B11.F & GGTGT & F11.F & CGGTAGA \\
\hline B12.F & AGGAT & F12.F & CTACGGA \\
\hline C01.F & ATTGA & G01.F & GCGGAAT \\
\hline $\mathrm{C} 02 . \mathrm{F}$ & CATCT & G02.F & TAGCGGA \\
\hline C03.F & ССТАC & G03.F & TCGAAGA \\
\hline C04.F & GAGGA & G04.F & TCTGTGA \\
\hline C05.F & GGAAC & G05.F & TGCTGGA \\
\hline C06.F & GTCAA & G06.F & ACGACTAC \\
\hline C07.F & TAATA & G07.F & TAGCTGCA \\
\hline C08.F & TACAT & G08.F & TAGGCCAT \\
\hline C09.F & TCGTT & G09.F & TGCAAGGA \\
\hline C10.F & GGTTGT & G10.F & TGGTACGT \\
\hline C11.F & CCAGCT & G11.F & TCTCAGTC \\
\hline C12.F & TTCAGA & G12.F & CCGGATAT \\
\hline D01.F & TAGGAA & H01.F & CGCCTTAT \\
\hline D02.F & GCTCTA & $\mathrm{H} 02 . \mathrm{F}$ & AACCGAGA \\
\hline D03.F & CCACAA & H03.F & ACAGGGAA \\
\hline D04.F & СТTCCA & H04.F & ACGTGGTA \\
\hline D05.F & GAGATA & H05.F & CCATGGGT \\
\hline D06.F & ATGCCT & H06.F & CGCGGAGA \\
\hline D07.F & AGTGGA & H07.F & CGTGTGGT \\
\hline D08.F & ACCTAA & H08.F & GCTGTGGA \\
\hline D09.F & ATATGT & H09.F & GGATTGGT \\
\hline D10.F & ATCGTA & H10.F & GTGAGGGT \\
\hline D11.F & CATCGT & H11.F & TATCGGGA \\
\hline D12.F & CGCGGT & H12.F & TTCCTGGA \\
\hline
\end{tabular}




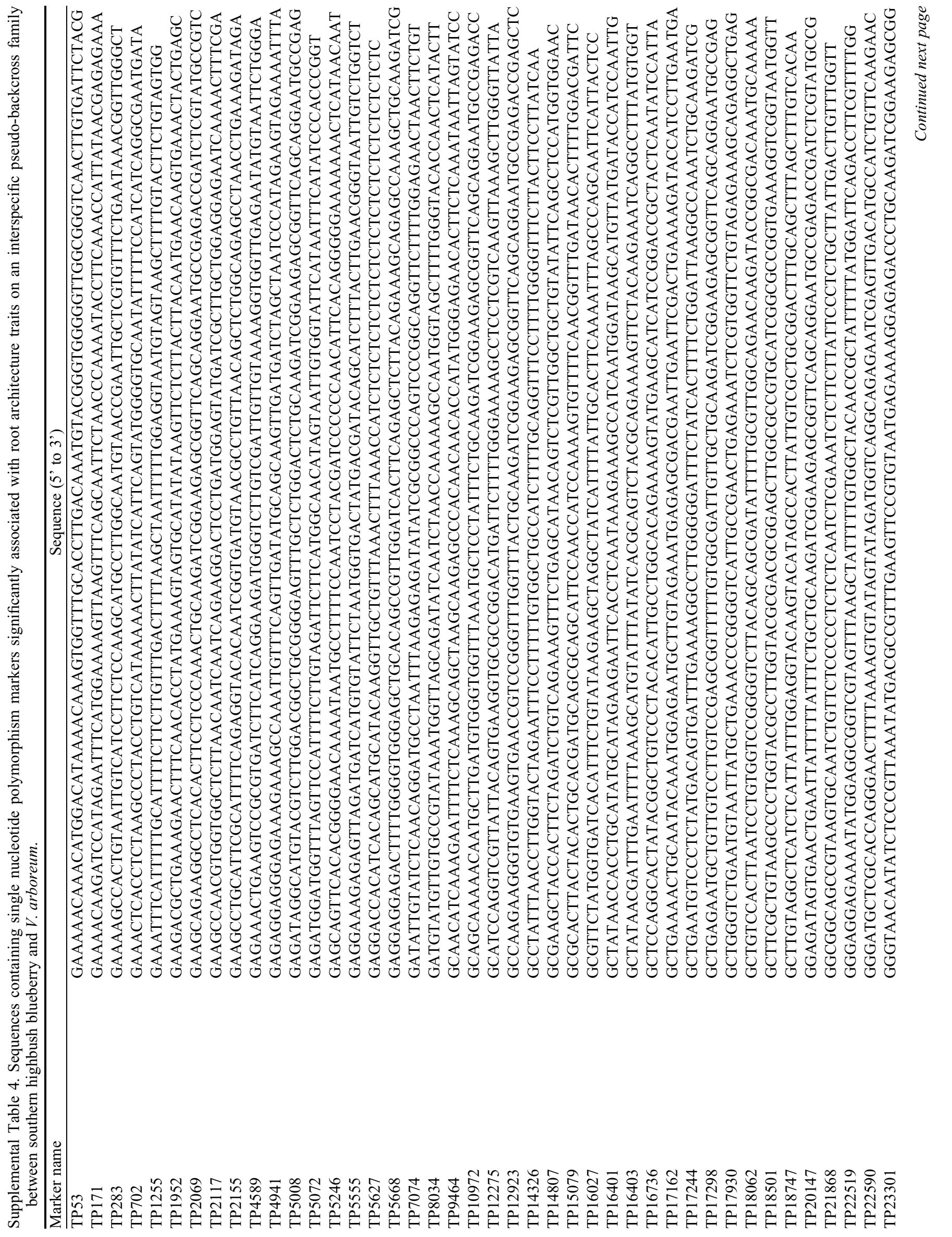




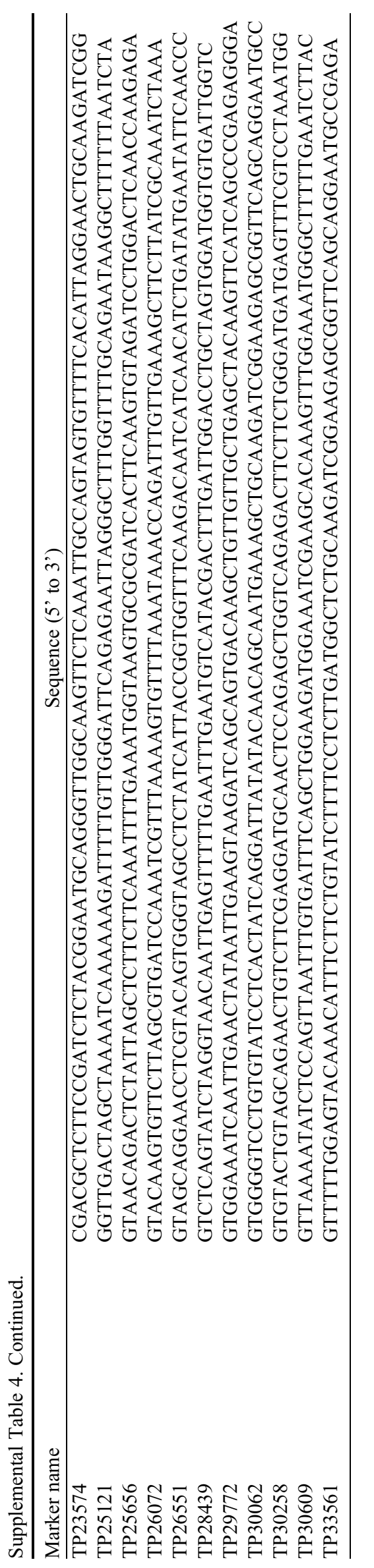

J. Amer. Soc. Hort. SCI. 141(5):1-3. 2016. 